\title{
Pearl oysters Pinctada margaritifera grazing on natural plankton in Ahe atoll lagoon (Tuamotu archipelago, French Polynesia)
}

\author{
Jonathan Fournier ${ }^{a}$, Christine Dupuy ${ }^{b}$, Marc Bouvy $^{c}$, Marine Couraudon-Réale ${ }^{a}$, Loïc Charpy ${ }^{d}$, \\ Stephane Pouvreau ${ }^{e}$, Gilles Le Moullac ${ }^{a, *}$, Marcel Le Pennec ${ }^{f}$, Jean-Claude Cochard ${ }^{g}$ \\ a IFREMER, Centre du Pacifique, BP 7004, 98719 Taravao, Tahiti, French Polynesia \\ ${ }^{b}$ CNRS and University of La Rochelle, LIENSs, UMR 6250, Batiment ILE, 2 rue Olympe de Gouges, 17000 La \\ ${ }^{c}$ IRD, UMR 5119, ECOSYM, University of Montpellier 2, Place Eugène Bataillon, 34095 Montpellier Cedex 5, \\ d IRD, CNRS and University of Méditerranée, UMR UPB, BP 529, 98713 Papeete, French Polynesia \\ e IFREMER, RBE, LPI, UMR 100, Presqu'île du Vivier, 29840 Argenton, France \\ f University de la Polynésie Française, EA42639, BP 6570, 98702 Faa'a, Tahiti, French Polynesia \\ ${ }^{\mathrm{g}}$ IFREMER, ODE, ER, Technopole de Brest-Iroise, BP 70, 29280 Plouzané, France \\ *: Corresponding author : Gilles Le Moullac, email address : gilles.le.moullac@ifremer.fr
} Rochelle, France France

\begin{abstract}
:
In atoll lagoons of French Polynesia, growth and reproduction of pearl oysters are mainly driven by plankton concentration. However, the actual diet of black-lip pearl oysters Pinctada margaritifera in these lagoons is poorly known. To fill this gap, we used the flow through chamber method to measure clearance rates of $P$. margaritifera in Ahe atoll lagoon (Tuamotu Archipelago, French Polynesia). We found: (i) that pearl oysters cleared plankton at a rate that was positively related to plankton biovolume, (ii) that nanoflagellates were the main source of carbon for the pearl oysters, and (iii) that the quantity and origin of carbon filtrated by pearl oysters was highly dependent on the concentration and composition of plankton. These results provide essential elements for the comprehension of growth and reproduction variability of pearl oysters in atoll lagoons of French Polynesia.
\end{abstract}

\section{Highlights}

Atoll lagoons of French Polynesia. Clearance rates of natural pico- to micro-plankton communities by Pinctada margaritifera. - High day to day fluctuations of plankton composition. Nanoplankton was the main source of carbon for the pearl-oyster. Plankton fluctuations lead to fluctuation in origin and quantity of carbon filtrated.

Keywords: Pinctada margaritifera ; Clearance rates ; French Polynesia ; Phytoplankton ; Protists

\section{Introduction}

For the last 40 years, farming of the black-lip pearl oyster Pinctada margaritifera has been the main aquaculture activity in French Polynesia atoll lagoons. In 2010, production and annual exportation of black pearls reached up to 12 metric tons, worth approximately 50 million Euros, making this industry the 2nd source of income for French Polynesia after tourism (Service de la Perliculture, pers. com.). However, this industry entirely relies on spat collection successes, which strongly depends on natural reproduction rates and on environmental conditions (Pouvreau et al., 2000a; Thomas et al., This issue). 
French Polynesian atoll lagoons have been characterized in the past by stable and homogeneous temperature and salinity (e.g. Buestel and Pouvreau, 2000). The planktonic biological processes are controlled by the hydrodynamic regime and specifically by the water residence time (Charpy et al. 1997; Delesalle and Sournia, 1992; Torréton et al., 2002), which is closely linked to atoll geomorphology and water exchanges through the reef rims (Andréfouët et al., 2001; Charpy and Blanchot, 1998; Sournia and Ricard, 1976; Dumas et al. this issue).

The same lagoons were also characterized by concentrations of chlorophyll $a$ and particulate organic carbon that rarely exceed $0.6 \mu \mathrm{g} \mathrm{l}^{-1}$ and $0.4 \mathrm{mg} \mathrm{l}^{-1}$, respectively (Buestel and Pouvreau, 2000; Charpy et al., 1997); and by the dominance of planktonic particles inferior to $5 \mu \mathrm{m}$ size which represented more than $70 \%$ of the total planktonic biomass (Buestel and Pouvreau, 2000; Charpy and Charpy-Roubaud, 1990; Niquil et al., 1998).

In the 1990 s the feeding strategy of $P$. margaritifera was investigated with various methods including laboratory and in situ experiments : (1) batch and flow-through chamber methods were used by Pouvreau et al. (1999) and Yukihira et al. (1998b) to measure clearance rates of $P$. margaritifera on various species of cultured algae, (2) batch method was used by Loret et al. (2000a) to study clearance rates of pearl oysters on natural assemblage of ciliates and dinoflagellates, (3) the biodeposit method was used by Pouvreau et al. (2000b) to measure in situ clearance rates of pearl oysters in Takapoto lagoon and, finally, (4) direct sampling of $P$. margaritifera gut content and HPLC analysis was used to determine which phytoplankton taxa were contributing to the pearl oysters' diet (Loret et al. 2000b).

These experiments demonstrated that (i) planktonic particles $<2 \mu \mathrm{m}$ were not efficiently retained, (ii) the diet of $P$. margaritifera included both autotrophic and heterotrophic plankton and (iii) $P$. margaritifera compensated the low concentration of efficiently retained planktonic particles (> $2 \mu \mathrm{m}$ ) by relatively high pumping rates to meet its energy requirements. However, this knowledge remained too limited to fully characterize, quantitatively, the pearl oysters' diet.

In this context, this study aims to measure the clearance rates of pearl oysters for six types of autotrophic and/or heterotrophic plankton (picoplankton, nanoflagellates, dinoflagellates, ciliates, phytoplankton $<2 \mu \mathrm{m}$ and phytoplankton $>2 \mu \mathrm{m}$ ), and to assess their relative contribution to the pearl oysters' diet in Ahe lagoon.

We selected the flow-through chamber method to measure clearance rates for two reasons: (i) it allows keeping the pearl oysters under the influence of natural fluctuations of environmental parameters and (ii) it facilitates repetitive sampling. 
Complementary techniques such as flow cytometry, microscope counts and chlorophyll $a$ extraction were used to measure the plankton concentration in the flow-through chambers.

\section{MATERIAL AND METHODS}

\section{Study site}

This study was conducted in Ahe atoll lagoon, located $500 \mathrm{~km}$ north of Tahiti Island in the north of the Tuamotu Archipelago (Figure 1). Ahe lagoon measures $142 \mathrm{~km}^{2}$ with a mean depth close to 42 $\mathrm{m}$. Ahe is defined as a semi-enclosed atoll. One active pass is located in the west part of the lagoon and several reef-flat spillways (less than $50 \mathrm{~cm}$ depth) are distributed along the reef rim, mainly in the south and west parts of the lagoon. The average water renewal time (ratio of lagoon volume to average water input rate) was estimated at 80 days (Dumas et al., This issue). With nearly 1350 spat collection stations and almost $11 \%$ of the lagoon dedicated to black-lip pearl oyster rearing, Ahe lagoon is a remarkable site for pearl culture and spat collection in French Polynesia.

Our study site and experimental set up were located in the northeast of the lagoon, $30 \mathrm{~m}$ off the coast, in a small pile building (Figure 1). Lagoon depth was approximately $2.5 \mathrm{~m}$. Experimental devices were protected from direct sunlight and rain. Pearl oysters were subjected to natural light regimes and experiments were conducted after an acclimation period of four days in the flowthrough grazing chambers.

The experiments took place in May 2008 (from $15^{\text {th }}-23^{\text {rd }}$ ), October 2008 (from $10^{\text {th }}-23^{\text {rd }}$ ) and April/May 2009 (from $28^{\text {th }}-10^{\text {th }}$ ). The rate at which pearl-oysters cleared phytoplankton from lagoon water (chlorophyll $a$ used as a proxy) was measured during each of these three experimental periods. The rate at which pearl-oysters cleared picoplankton, nanoflagellates, dinoflagellates and ciliates from lagoon water were only measured during October 2008 experiments.

\section{Environmental parameters}

Hourly wind direction and velocity were obtained from Takaroa atoll meteorological station (Météo

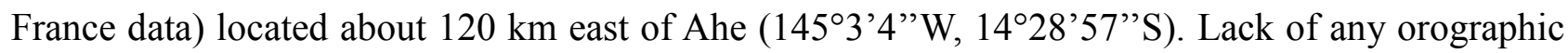
effects around atolls allows using this distant measurement, which was in good agreement with local value and numerical models output at Ahe atoll (Dumas et al., This issue).

Water temperature $\left({ }^{\circ} \mathrm{C}\right)$ and salinity (PSU) were obtained from a Sea Bird probe (SBE V19 plus) immersed at a 10 meter depth, next to an experimental breeding station located approximately $3 \mathrm{~km}$ away from our study site (Figure 1). 


\section{Phytoplankton concentration}

Water samples $(200 \mathrm{ml})$ were filtered firstly on Millipore filters $(2 \mu \mathrm{m}$ of pore size $)$ and then on $\mathrm{GF} / \mathrm{F}$ Whatman filters (ca. $0.7 \mu \mathrm{m}$ pore size). Chlorophyll $a(\mathrm{Chl} a)$ retained on these filters was extracted from phytoplankton cells during $4 \mathrm{~h}$ in the dark at $4^{\circ} \mathrm{C}$ in $6 \mathrm{ml}$ of methanol $100 \%$. Chl $a$ concentration in these extracts was determined using a Turner design TD 700 fluorimeter calibrated with Chl $a$ standard (Sigma) and equipped with the set of optical filters recommended by Welshmeyer (1994) for direct measurement of Chl $a$.

We measured concentration of phytoplankton $<2 \mu \mathrm{m}\left(\mathrm{Chl} a<2 \mu \mathrm{m}\right.$, in $\left.\mu \mathrm{g} \mathrm{l}^{-1}\right)$ and $>2 \mu \mathrm{m}(\mathrm{Chl} a>$ $2 \mu \mathrm{m}$, in $\mu \mathrm{g}^{-1}$ ) respectively from the $\mathrm{Chl} a$ concentration measured in GF/F filters extracts and from the Chl $a$ concentration in Millipore filters extracts. To convert Chl $a>2 \mu \mathrm{m}$ and Chl $a<2$ $\mu \mathrm{m}$ concentrations into carbon biomass, we used ratios equal to $50 \mu \mathrm{gC} \mu \mathrm{gChl} a^{-1}$ and to $82 \mu \mathrm{gC}$ $\mu \mathrm{gChl} a^{-1}$, respectively (Charpy and Charpy-Roubaud, 1990; Charpy, 1996).

\section{Picoplankton concentration}

In this study, picoplankton abundance (Pico. in cell $1^{-1}$ ) is defined as the sum of bacteria, cyanobacteria (Synechococcus sp. and Prochlorococcus sp.) and picoeukaryotes abundances.

Bacteria and picoautotrophic cells were fixed with $0.2 \mu \mathrm{m}$ filtered formaldehyde (final concentration $2 \%$ ) and frozen in liquid nitrogen $\left(\mathrm{N}_{2}\right)$. Bacterial cells were counted by flow cytometry using the method described by Marie et al. (1997). One mL formaldehyde-fixed subsamples were incubated with DAPI at a final concentration of $1 / 10,000$ for 15 min at room temperature in the dark. Each subsample was counted using a MoFlo cytometer (Dako Colorado Inc., Fort Collins, CO, USA). Stained bacterial cells, excited at $488 \mathrm{~nm}$, were enumerated according to their right-angle light scatter (RALS) and green fluorescence (FL1) measured using a 530/30 nm filter. These cell parameters were recorded on a 4 decade logarithmic scale mapped onto 1024 channels. Fluorescent beads $(0.94 \mu \mathrm{m}$, Polysciences Inc., Warrington, PA, USA) were systematically added to each sample. Standardized RALS and FL1 values (cell RALS and FL1 divided by $0.94 \mu \mathrm{m}$ beads RALS and FL1, respectively) were used as an estimation of the relative size and nucleic acid content of bacterial cells, respectively (Troussellier et al., 1995). Listmode files were analyzed using SUMMIT software (Dako Colorado Inc., Fort Collins, CO, USA).

Picophytoplankton (Prochlorococcus sp. and Synechococcus sp. cells) and autotrophic picoeukaryotes counts were performed with the same flow cytometer set up as described above. Cells excited at $488 \mathrm{~nm}$ were detected and directly enumerated according to their FALS and RALS 
properties and their orange fluorescence $(585 / 42 \mathrm{~nm})$ and red fluorescence $(>650 \mathrm{~nm})$ due to phycoerythrin and chlorophyll pigments, respectively. Fluorescent beads $(0.94 \mu \mathrm{m})$ were also systematically added to each sample. Listmode files were analyzed using SUMMIT software (Dako Colorado Inc., Fort Collins, CO, USA).

To calculate an average carbon conversion factor for picoplankton, we used conversion factors of $14 \mathrm{fgC}$ cell $^{-1}$ (Gundersen et al., 2002), $60 \mathrm{fgC} \mathrm{cell}^{-1}, 178 \mathrm{fgC}$ cell $^{-1}$ (Charpy and Blanchot, 1998) and $836 \mathrm{fgC} \mathrm{cell}^{-1}$ (Verity et al.,1992) for bacteria, Prochlorococcus sp., Synechococcus. sp. and for picoeukaryotes respectively. These values were averages and weighted by the mean abundance of heterotrophic bacteria, Prochlorococcus sp., Synechococcus sp. and picoeukaryotes measured during this study. This community-scale conversion factor was then use to convert the total picoplankton concentration (cell $\left.1^{-1}\right)$ into carbon biomass $\left(\mu \mathrm{gC} 1^{-1}\right)$.

Similarly, to calculate an average biovolume $\left(\mathrm{BV}, \mu \mathrm{m}^{3}\right)$ per picoplankton cell we used biovolumes of $0.035 \mu \mathrm{m}^{3}, 0.11 \mu \mathrm{m}^{3}, 0.38 \mu \mathrm{m}^{3}$ and $1.2 \mu \mathrm{m}^{3}$ per heterotrophic bacteria (Sakka et al., 2000), Prochlorococcus sp. cell, Synechococcus sp. cell (Charpy and Blanchot, 1998), and picoeukaryote cell, respectively. These values were weighted by the mean abundance measured for each plankton type.

\section{Nanoplankton and microplankton concentration}

The taxonomic determination of protists was carried out in accordance with systematics literature (Kahl, 1931; Lee, 1985; Nezan, 1996; Paulmier, 1997; Ricard, 1987; Sournia, 1986).

For microplankton counts (dinoflagellates and ciliates), water samples (1 liter) were fixed with alcalin lugol iodine ( $2 \%$ final concentration). A first period of sedimentation was conducted during $24 \mathrm{~h}$ after which the top $900 \mathrm{~mL}$ of sample was slowly siphoned off with small-bore tubing. The remaining $100 \mathrm{~mL}$ was then stored at $4{ }^{\circ} \mathrm{C}$ in the dark before enumeration. A second sedimentation of $24 \mathrm{~h}$ was carried out in Utermöhl settling chamber (Hydro-Bios combined plate chamber) and cell enumeration was made at 400 magnification using a Leica DMI 3000B inverted microscope with interference contrast. Cells were counted in every microscope field (at least 60 fields per samples) for five transversal bands covering the settling chamber width and disposed at equal distance of each other.

For nanoplankton counts, water samples $(25 \mathrm{ml})$ were fixed and preserved with paraformaldehyde ( $1 \%$ final concentration). Samples were concentrated to $10 \mathrm{ml}$ with a filtration tower mounted with 
$0.8 \mu \mathrm{m}$ pore size black polycarbonate filters (Nuclepore) and stained with DAPI $\left(2.5 \times 10^{-4} \mathrm{~g}^{-1}\right.$

final concentration). Enumeration of stained nanoplanktonic cells was made under UV light excitation on at least 15 randomly selected fields, at the magnification of x1000.

Nanoplankton and microplankton abundances (in cell $\mathrm{l}^{-1}$ ) were computed using the following equation :

$$
\mathrm{A}=\left(\mathrm{N}_{\mathrm{C}} /\left(\mathrm{N}_{\mathrm{MF}} \times \mathrm{S}_{\mathrm{MF}}\right)\right) \times \mathrm{S}_{\mathrm{SC}} \times 1000 / \mathrm{V}_{\mathrm{S}}
$$

where $\mathrm{A}=$ abundance of nanoplankton or microplankton (cell $\mathrm{l}^{-1}$ ), $\mathrm{N}_{\mathrm{C}}=$ total number of cells (in cell), $\mathrm{N}_{\mathrm{MF}}=$ number of counted microscopic fields, $\mathrm{S}_{\mathrm{MF}}=$ area of one microscopic field $\left(\mathrm{mm}^{2}\right), \mathrm{S}_{\mathrm{SC}}$ $=$ area of settling chamber or filter $\left(\mathrm{mm}^{2}\right), \mathrm{V}_{\mathrm{S}}=$ sample volume (1).

An average biovolume for dinoflagellates (200 cells) and ciliates (about 50 cells) was calculated using the mean length and width of cells, which were determined with a calibrated ocular micrometer.

Using these mean biovolumes and the biovolume to carbon content relationship from MendenDeuer and Lessard (2000), we calculated the carbon conversion factors for both dinoflagellates and ciliates. These conversion factors were then used to convert dinoflagellates and ciliates concentration (cell $\left.1^{-1}\right)$ into carbon biomass $\left(\mu \mathrm{gC}^{-1}\right)$.

For nanoplankton cells, we assumed an average biovolume of $509 \mu \mathrm{m}^{3}$ which was calculated from the cell diameters of chlorophytes, prasinophytes and cryptophytes measured by Loret et al. (2000b) in Takapoto lagoon and we assumed an average conversion factor of $4.7 \times 10^{-6} \mu \mathrm{gC}$ per cell of nanoplankton as in Ferrier-Pagès and Furla (2001).

\section{Flow through chambers}

After a critical analysis of the methodological shortcomings and possible misinterpretations related to the different methods of studying bivalve feeding processes (Bayne, 2004; Filgueira et al., 2006; Pascoe et al., 2009; Petersen, 2004 and Riisgård, 2004 for the most recent reviews) we selected the flow through chamber method for the measurement of in situ clearance rates of Pinctada margaritifera.

Water was pumped from the lagoon at 1 meter deep to a 80 liter reservoir tank at a flow rate of approximately $300 \mathrm{l} \mathrm{h}^{-1}$. We used a peristaltic pump to avoid the destruction of fragile planktonic organisms. From this tank, lagoon water was distributed by gravity into flow through grazing chambers. Flow rates were adjusted (between $51 \mathrm{~h}^{-1}$ and $681 \mathrm{~h}^{-1}$ ) in each flow through chamber to 
prevent the pearl oyster from removing more than 30\% of chlorophyll $a$ (Hawkins et al., 1999). A control flow through chamber without pearl oyster was maintained in the same configuration as our grazing chambers.

To avoid "recirculation issues" and to ensure "sufficient mixing of the exhalant flow with the flow bypassing the bivalve" (Riisgård, 2001), our grazing chambers were divided into three compartments (Figure 2): the inflow compartment where the water was entering, the grazing compartment where the pearl oyster was filtering and the outflow compartment where the water was siphoned off. Inflow and grazing compartments were separated out by 2 homogenization grids. In the grazing compartment, one pearl oyster was maintained on a PVC support at mid height of the water column and the exhalant flow was directed to the outflow compartment through a PVC reduction of $5 \mathrm{~cm}$ of diameter. In the outflow compartment, water was siphoned off $5 \mathrm{~cm}$ under the surface.

The siphoned water was sampled with $500 \mathrm{ml}$ graduated test tube simultaneously from the control chamber and from the grazing chambers.

Experiments with the smallest pearl oysters (25 to $30 \mathrm{~mm}$ in height) were conducted in 25 liters grazing chambers $(20 \mathrm{~cm}$ in diameter and $50 \mathrm{~cm}$ in length) whereas experiments with pearl oysters measuring $41 \mathrm{~mm}$ to $115 \mathrm{~mm}$ in height were conducted in 50 liters grazing chambers $(20 \mathrm{~cm}$ in diameter and $100 \mathrm{~cm}$ in length).

All flow trough chambers were emptied and cleaned every single day to remove faeces and pseudofaeces produced by the pearl oysters.

\section{Pearl Oysters}

A total of 16 pearl oysters were used during these experiments. In May 2008, experiments were conducted with pearl oysters measuring $42 \pm 1 \mathrm{~mm}$ in height (mean $\pm \mathrm{sd})(\mathrm{n}=4)$ and with $113 \pm 4 \mathrm{~mm}$ height pearl oysters $(n=2)$. In October 2008, experiments were conducted with $28 \pm 2 \mathrm{~mm}$ height pearl oysters $(n=4)$, and in May 2009 , with $75 \pm 6 \mathrm{~mm}$ height pearl oysters $(n=6)$. For each size class of pearl oysters, sampling strategy is indicated in Table 1.

The smallest pearl oysters ( 25 to $43 \mathrm{~mm}$ in height) were bred at the Ifremer center's hatchery of Vairao (Tahiti Island) and were stored in Ahe lagoon at one meter deep at least one week before starting the experiments. Pearl oysters from $74 \mathrm{~mm}$ to $115 \mathrm{~mm}$ came from the "Motu Tahiri" pearl farm in Ahe. All epibionts were cleaned off and pearl oysters were allowed to recover from any 
potential stress during three days before starting the starting the experiments. Sampling was then

\section{Clearance rates}

Clearance rate is defined as the volume of water entirely cleared of plankton by one pearl oyster per unit of time. It was calculated for each plankton type with the following equation, modified from Hildreth and Crisp (1976) :

$$
\mathrm{CRi}=\operatorname{Fr} \times(\mathrm{Cc}-\mathrm{Cg}) / \mathrm{Cg}
$$

with $\mathrm{CRi}=$ clearance rates of pearl-oyster (in $1 \mathrm{~h}^{-1}$, per individual), $\mathrm{Cc}$ and $\mathrm{Cg}=$ concentration of plankton at the exit of the control $(\mathrm{Cc})$ and grazing $(\mathrm{Cg})$ flow trough chambers (in $\mu \mathrm{g} \mathrm{Chl} a \mathrm{l}^{-1}$ or in cell $\left.\mathrm{l}^{-1}\right), \mathrm{Fr}=$ flow rate in the grazing flow through chamber $\left(\mathrm{h}^{-1}\right)$.

Clearance rates is known to follow an allometric relationship of the type $\mathrm{CR}=\mathrm{aDW}^{\mathrm{b}}$ with $\mathrm{DW}=$ freeze dried fresh weight (in $g$ ), $a$ and $b=$ linear regression coefficients of $\log \left(\mathrm{CR}_{\mathrm{i}}\right)$ vs $\log (\mathrm{DW})$ (e.g. Pouvreau et al., 1999). Following this relationship, all CRi values were divided by DW ${ }^{\mathrm{b}}$ and standardized clearance rates $(\mathrm{CR})$ were expressed in $1 \mathrm{~h}^{-1} \mathrm{~g}^{-1}$.

\section{Carbon retention rates}

Clearance rates can be defined as the capacity of pearl oysters to filter and retain particles from their environment. However, the amount of carbon retained by $P$. margaritifera also depends on the plankton biomass. To assess the contribution of each plankton type to the diet of P. margaritifera, we estimated carbon retention rates by the following equation :

$$
\mathrm{RR}=\mathrm{CB} \times \mathrm{CR} \text {, }
$$

where $\mathrm{RR}=$ Retention Rates of carbon in $\mu \mathrm{gC} \mathrm{g} \mathrm{g}^{-1} \mathrm{~h}^{-1}, \mathrm{CB}=$ Carbon Biomass in $\mu \mathrm{gC} \mathrm{l}^{-1}, \mathrm{CR}=$ Clearance Rates in $\left(1 \mathrm{~h}^{-1}\right)$.

\section{Statistics}

All analysis were conducted with the $\mathrm{R}$ freeware (http://www.r-project.org/). All data sets were tested for normality (Shapiro-Wilk test) and homogeneity of variance (Bartlett test). In most cases, data had to be log-transformed (natural $\log$ of $X$ ). 
As wind velocity, salinity and water temperature data were not normal, highly heteroscedastic and

were also highly asymmetric between surveys, we only used their mean and associated 95\% confidence interval (Efron and Tibshirani, 1986) for each survey.

Two-way analysis of variance (ANOVA) were used (i) to compare concentration of Chl $a$ among surveys and within size class $(>2 \mu \mathrm{m}$ and $<2 \mu \mathrm{m}$ ) and (ii) to compare CR of pearl-oysters among surveys and within size-class of Chl $a(>2 \mu \mathrm{m}$ and $<2 \mu \mathrm{m})$. A posteriori multiple comparisons were carried out using Tukey HSD tests.

We used Pearson's correlation to examine relationships between Chl $a$ concentration $(>2 \mu \mathrm{m}$ and $<$ $2 \mu \mathrm{m})$, flow rates in the flow trough grazing chambers and clearance rates of pearl oysters.

For each survey, exact binomial tests were used to compare the percentage of carbon retained by pearl oysters from Chl. $a<2 \mu \mathrm{m}$ and Chl. $a>2 \mu \mathrm{m}$.

Non parametric Kruskal-Wallis tests were used to compare (1) abundance of ciliates, dinoflagellates, nanoplankton and picoplankton measured in October 2008, (2) clearance rates of ciliates, dinoflagellates, nanoplankton and picoplankton measured in October 2008. A posteriori multiple comparisons were carried out using the non parametric Steel-Dwass test (Critchlow and Fligner, 1991; Spurrier, 2006).

In all tests, significance was determined with an alpha level of 0.05 .

\section{RESULTS}

\section{Temperature, salinity, wind direction and speed}

Mean water temperature ranged from $26.82 \pm 0.01{ }^{\circ} \mathrm{C}$ (in October 2008) to $29.1 \pm 0.05{ }^{\circ} \mathrm{C}$ (in May 2009). Mean salinity ranged from of $36.16 \pm 0.03$ (in October 2008) to 36.87 \pm 0.09 in (May 2008) (Table 2).

East and southeast winds blew continuously in October 2008 with the highest velocity of the three surveys $\left(8.63 \pm 0.41 \mathrm{~m} \mathrm{~s}^{-1}\right)$. In May 2008 and in May 2009, winds were predominantly blowing from the northwest and northeast (more than $75 \%$ of the time) with lower velocity $\left(3.0 \pm 1.7 \mathrm{~m} \mathrm{~s}^{-1}\right.$ and $2.7 \pm 1.4 \mathrm{~m} \mathrm{~s}^{-1}$ respectively) (Table 2). 
Variations of Chl $a<2 \mu \mathrm{m}$ and Chl $a>2 \mu \mathrm{m}$ concentrations and of clearance rates are presented in

Figure 3. Both Chl $a>2 \mu \mathrm{m}$ and $\mathrm{Chl} a<2 \mu \mathrm{m}$ concentrations showed significant variations between surveys (Tables 3 and Table 4). Chl $a>2 \mu \mathrm{m}$ was lower than Chl $a<2 \mu \mathrm{m}$ in May 2008 and in May 2009, while concentrations were not significantly different in October 2008, a period when we observed the highest $\mathrm{Chl} a>2 \mu \mathrm{m}$ concentration $\left(1.31 \mu \mathrm{g} \mathrm{l}^{-1}\right)$.

Conversion factors presented in Table 5 were used to convert mean Chl $a>2 \mu \mathrm{m}$ and Chl $a<2 \mu \mathrm{m}$ concentration into carbon biomass. Phytoplankton biomass ranged from $23 \mu \mathrm{gC} 1^{-1}$ (May 2009) to $42 \mu \mathrm{gC} 1^{-1}$ (October 2008).

The biomass temporal trends were similar to concentration trends. In May 2008 and May 2009, biomass of Chl $a<2 \mu \mathrm{m}$ was higher than biomass Chl $a>2 \mu \mathrm{m}$ while there was no significant difference between biomass $\mathrm{Chl} a<2 \mu \mathrm{m}$ and Chl $a>2 \mu \mathrm{m}$ in October 2008.

The allometric relationship between $\mathrm{Chl} \mathrm{a}>2 \mu \mathrm{m}$ clearance rates and freeze dried dry flesh weight is presented in Figure 4. Linear regression of $\log (\mathrm{CRi})$ on $\log (\mathrm{DW})$ was significant $\left(\mathrm{r}^{2}=0.87\right.$ and $\mathrm{p}<0.001, \mathrm{n}=16$ ) and we established that $\mathrm{CRi}=13.3 \mathrm{DW}^{0.62}$. This relationship was further used to standardize clearance rates for a $1 \mathrm{~g}$ DW pearl oyster $\left(\mathrm{CR}=\mathrm{CRi} / \mathrm{DW}^{0.62}\right)$.

In all surveys, pearl oysters cleared Chl $a>2 \mu \mathrm{m}$ at a higher rate than Chl $a<2 \mu \mathrm{m}$. Mean CR did not show any significant variations between surveys (Table 4). CR of pearl oysters was not influenced by variations of Chl $a<2 \mu \mathrm{m}$ and Chl $a>2 \mu \mathrm{m}$ concentration, neither by flow rates (Table 6).

In May 2008, pearl oysters retained significantly higher quantities of carbon from Chl $a<2 \mu \mathrm{m}$ than from Chl $a>2 \mu \mathrm{m}$. In October 2008, it was the opposite : pearl oysters retained significantly higher quantities of carbon from Chl $a>2 \mu \mathrm{m}$ than from Chl $a<2 \mu \mathrm{m}$. In May 2009, pearl oysters retained similar quantities of carbon from $\mathrm{Chl} a>2 \mu \mathrm{m}$ and from $\mathrm{Chl} a<2 \mu \mathrm{m}$ (Table 3).

\section{Planktonic microorganisms : concentration, clearance rates and carbon retention}

This section presents results of the October 2008 survey, when the contribution of all plankton types to the pearl oysters diet was assessed. Variations of plankton concentrations and clearance rates are presented in Figure 3. Mean plankton concentration, mean clearance rates and mean carbon retention rates are presented in Table 3.

In October 2008, picoplankton and nanoflagellates were the two most abundant plankton types (Table 3). Picoplankton concentration ranged from $1.92 \times 10^{8}$ cell $1^{-1}$ to $3.09 \times 10^{8}$ cell $1^{-1}$ with a 
mean of $2.64 \pm 0.71 \times 10^{8}$ cell $1^{-1}$. We calculated an average carbon content per cell of picoplankton of $1.1 \times 10^{-7} \mu \mathrm{gC} \mathrm{Cell}{ }^{-1}$ (Table 5). Nanoflagellates concentration ranged from $3.77 \times 10^{7}$ cell $^{-1}$ to $6.04 \times 10^{7}$ cell $1^{-1}$ with a mean concentration of $5.25 \pm 0.80 \times 10^{7}$ cell $^{-1}$. Dinoflagellates concentration ranged from $0.86 \times 10^{4}$ cell $1^{-1}$ to $12.3 \times 10^{4}$ cell $1^{-1}$ with a mean concentration of $5.09 \pm 4.32 \times 10^{4}$ cell $^{-1}$. From their mean length $(14.1 \pm 5.0 \mu \mathrm{m})$ and width $(10.9 \pm 3.7 \mu \mathrm{m})$, we calculated an average biovolume of $1,600 \mu \mathrm{m}^{3}$ and an average carbon content per cell of $2.2 \times 10^{-4}$

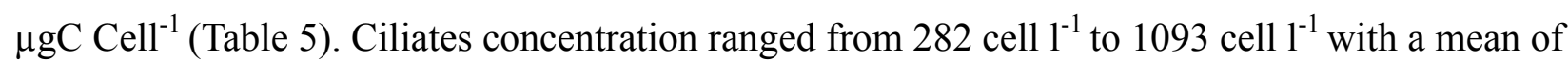
$740 \pm 354$ cell $^{-1}$ (Table 3, Figure 3). From their mean length $(30.3 \pm 13.4 \mu \mathrm{m})$ and width $(23.4 \pm 9.4$ $\mu \mathrm{m})$ we calculated an average biovolume of $18,000 \mathrm{~m}^{3}$ and an average carbon content per cell of $2.1 \times 10^{-3} \mu \mathrm{gC} \mathrm{Cell}^{-1}$ (Table 5).

The mean concentration of picoplankton, nanoflagellates, dinoflagellates and ciliates were converted into carbon biomass using the conversion coefficients presented in Table 5. The total carbon biomass was $288 \mu \mathrm{gC} \mathrm{l}^{-1}$ and nanoflagellates constituted the bulk of total plankton biomass $(85 \%)$.

Mean clearance rates of pearl oysters increased with the size of plankton ( from $0.5 \mathrm{~h} \mathrm{~h}^{-1} \mathrm{~g}^{-1}$ for picoplankton to $18.71 \mathrm{~h}^{-1} \mathrm{~g}^{-1}$ for ciliates $)$ and there was a significant relationship $\left(\mathrm{r}^{2}=0.71, \mathrm{p}=\right.$ $0.000, n=16$ ) between mean clearance rates of pearl oysters and biovolumes of plankton cells : CR $=0.42 \ln (\mathrm{BV})+0.35$ (Figure 5).

Nanoflagellates were the dominant source of carbon retained by pearl oysters in October 2008 (93\%). The second source of carbon for pearl oysters were dinoflagellates $(6 \%)$.

\section{DISCUSSION}

\section{Plankton concentration}

Phytoplankton concentration measured during this study was in the upper range of phytoplankton concentration measured in Ahe lagoon and in several other Tuamotu atoll lagoons (Table 7). In October 2008 phytoplankton concentration reached values $>1 \mu \mathrm{gChl} a \mathrm{I}^{-1}$ with a mean concentration above $0.65 \mu \mathrm{gChl} a \mathrm{l}^{-1}$. In October 2008, we also observed (i) concentration of dinoflagellates being in the upper range of values measured in other lagoons (Takapoto and Tikehau) (Table 7), (ii) concentration of nanoflagellates that were approximately 10 times greater than those measured in Rangiroa, Tikehau and in Ahe lagoon at other sites/periods (Table 7), (iii) concentrations of picoplankton in the lower range of values reported in other atolls (Table 7). Thus, during the October 2008 experiments, the biomass of $>2 \mu \mathrm{m}$ planktonic particles (nanoplankton + dinoflagellates + ciliates) represented more than $90 \%$ of the total planktonic 
biomass. These observations are unusual in Tuamotu atoll lagoons where the biomass of $>2 \mu \mathrm{m}$

planktonic particles is approximately $36 \%$ of the total planktonic biomass, as reviewed by Pouvreau et al. (2000a).

Previous studies in French Polynesian atolls have shown that plankton concentration variations can be significant at small spatial and/or temporal scale, despite the average low concentration of plankton and despite weak seasonal trends (Buestel and Pouvreau, 2000; Charpy et al., This issue; Fournier et al, This issue; González et al., 1998; Pagano et al., This issue; Sournia and Ricard, 1976; Thomas et al., 2010). However, the exact mechanisms responsible for these changes remain unclear. Changes in hydrodynamic regimes are likely causal factors and warrant further investigations. The availability of 3D circulation numerical models will allow in a near future a better understanding of these processes (Dumas et al. This issue).

\section{Clearance rates}

Mean CR of pearl oysters ranged between $11.81 \mathrm{~h}^{-1} \mathrm{~g}^{-1}$ and $18.71 \mathrm{~h}^{-1} \mathrm{~g}^{-1}$ for plankton $>2 \mu \mathrm{m}(\mathrm{Chl}$ a $>2 \mu \mathrm{m}$, nanoflagellates, dinoflagellates and ciliates). These values are in the range of CR measured by Yukihira et al. (1998b) $\left(12.31 \mathrm{~h}^{-1} \mathrm{~g}^{-1}\right)$ and Pouvreau et al. (1999) $\left(25.91 \mathrm{~h}^{-1} \mathrm{~g}^{-1}\right)$ during laboratory experiments with a monospecific solution of Isochrysis galbana retained at $98 \%$ by $P$. margaritifera.

Clearance rates of $P$. margaritifera are also close to clearance rates of the oyster Crassostrea gigas measured under low seston load conditions in Thau lagoon in France $\left(161 \mathrm{~h}^{-1} \mathrm{~g}^{-1}\right.$ for $>5 \mu \mathrm{m}$ flagellates) (Dupuy et al., 2000).

During our experiments, we did not measure any influence of plankton concentration variations on clearance rates (Table 6). However, bivalves filtration performances are known to decrease when seston load increases (e.g., Pouvreau et al., 2000b for P. margaritifera). Species inhabiting high seston load environments display lower clearance rates than species in low seston load environments (Jørgensen, 1996; Yukihira et al., 1998a, Trottet et al., 2008). The low load of atoll lagoons compared to many temperate coastal environments explains the typically high, and stable, CR of P. margaritifera (and $C$. gigas when in a low seston load environment).

Clearance of picoplankton by pearl oysters was extremely low compared to clearance of nanoplankton and microplankton. Moreover, there was a clear positive relationship between clearance rates of P. margaritifera and biovolume of plankton cells (Figure 5). This relationship, obtained in situ, is in agreement with the relationship between retention efficiency and particle size 
obtained in laboratory by Pouvreau et al. (1999). Finally, numerous studies have shown that this relationship was explained by the gill structure, and especially by the disposition of cirri on gill filaments (e.g Pouvreau et al., 1999; Silverman et al., 1996; Wright et al., 1982).

For P. margaritifera, in situ clearance rates data are scarce in literature. However, comparisons between clearance rates values measured during our experiments and clearance rates values measured by Loret et al. (2000a) in Takapoto lagoon again highlight this obvious relationship between clearance rates and particle size / biovolume.

Indeed, mean CR of small (length : $14.1 \mu \mathrm{m}$; width : $10.9 \mu \mathrm{m}$ ) dinoflagellates $\left(161 \mathrm{~h}^{-1} \mathrm{~g}^{-1}\right)$ measured during this study was half lower than $\mathrm{CR}\left(331 \mathrm{~h}^{-1} \mathrm{~g}^{-1}\right)$ of large (length : $83 \mu \mathrm{m}$; width : 35 $\mu \mathrm{m})$ dinoflagellates measured by Loret et al (2000a).

Conversely, mean CR of small (length : $30.3 \mu \mathrm{m}$; width : $23.4 \mu \mathrm{m}$ ) ciliates $\left(191 \mathrm{~h} \mathrm{~h}^{-1} \mathrm{~g}^{-1}\right)$ measured during this study was in the range of $\mathrm{CR}$ of $10 \mathrm{~h} \mathrm{~h}^{-1} \mathrm{~g}^{-1}$ for Amphileptus sp (length : $55 \mu \mathrm{m}$; width : $21 \mu \mathrm{m}$ ) and of $20 \mathrm{~h}^{-1} \mathrm{~g}^{-1}$ for Strombidium sp. (length : $50 \mu \mathrm{m}$; width : $30 \mu \mathrm{m}$ ) measured by Loret et al. (2000a) in Takapoto lagoon.

\section{Carbon retention rates}

Obviously, plankton concentration measured in October 2008 was exceptionally high and did not represent the average plankton concentration in Ahe lagoon. Thus, to assess the average amount of carbon retained by pearl oysters in Ahe lagoon, we calculated the average concentration of Chl. $a<$ $2 \mu \mathrm{m}$, Chl. $a>2 \mu \mathrm{m}$, picoplankton, nanoflagellates, dinoflagellates and ciliates from literature data (Table 8). Then, we converted these average plankton concentrations into their respective carbon biomass using the conversion factors in Table 5. Finally, we calculated the average carbon retention rates of pearl oysters for each plankton fraction using clearance rates measured in October 2008. The average biomass of phytoplankton in Ahe was $26 \mu \mathrm{gC} 1^{-1}$ and $\mathrm{Chl} a>2 \mu \mathrm{m}$ represented $27 \%$ of this biomass. However, pearl oysters retained similar amounts of carbon from $\mathrm{Chl} a<2 \mu \mathrm{m}$ and from $\mathrm{Chl} a>2 \mu \mathrm{m}$ (ca. $100 \mu \mathrm{gC} \mathrm{h}^{-1} \mathrm{~g}^{-1}$ ) (Table 8).

The average total panktonic carbon biomass was $103 \mu \mathrm{gC} \mathrm{l}^{-1}$ (Table 8). Picoplankton represented $69 \%$ of this total carbon biomass and nanoflagellates represented $24 \%$. Finally, dinoflagellates and ciliates represented only $7 \%$. In contrast, carbon retained by pearls oysters originated mainly from nanoflagellates (64\%), then from dinoflagellates and ciliates (27\%), and finally from picoplankton $(8 \%)$.

In October 2008, pearl oysters retained almost 8 times more planktonic carbon than average (ca. $3000 \mu \mathrm{gC} \mathrm{h}^{-1} \mathrm{~g}^{-1}$ and $400 \mu \mathrm{gC} \mathrm{h} \mathrm{g}^{-1} \mathrm{~g}^{-1}$, respectively). 
In Takapoto lagoon, pearl oysters retained similar quantities of carbon from dinoflagellates $(64 \mu \mathrm{gC}$

$\left.\mathrm{h}^{-1} \mathrm{~g}^{-1}\right)$ compared to the average in Ahe $\left(70 \mu \mathrm{gC} \mathrm{h}^{-1} \mathrm{~g}^{-1}\right)$. Dinoflagellates were larger in Takapoto lagoon but their concentration was lower than in Ahe lagoon (Loret et al., 2000a).

Pearl oysters retained higher quantities of carbon in Takapoto from ciliates $\left(86 \mu \mathrm{gC} \mathrm{h} \mathrm{h}^{-1} \mathrm{~g}^{-1}\right)$ compared to the average in Ahe $\left(55 \mu \mathrm{gC} \mathrm{h}^{-1} \mathrm{~g}^{-1}\right)$, where they were smaller and less abundant than in Takapoto (Loret et al., 2000a).

To our knowledge, there is no comparable in situ study that has measured the relative contribution of pico- nano- and micro- plankton to the diet of a tropical bivalve. In temperate environments, Trottet et al. (2008) and Dupuy et al. (2000) investigated the relative contribution of pico- nano- and micro- plankton in the blue mussel diet (Mytilus edulis) and in the cupped oyster diet (Crassostrea gigas), respectively. In Thau lagoon (France), C. gigas retained a total of $1634 \mu \mathrm{gC} \mathrm{h}^{-1} \mathrm{~g}^{-1}$, and in Grand Entrée lagoon (Canada), total carbon retention of M. edulis ranged from $160 \mu \mathrm{gC} \mathrm{h}{ }^{-1} \mathrm{~g}^{-1}$ to $1467 \mu \mathrm{gC} \mathrm{h} \mathrm{g}^{-1}$.

In Thau lagoon, diatoms represented $87 \%$ of the total planktonic biomass and $80 \%$ of the carbon retained by $C$. gigas while in Grande Entrée lagoon, ciliates represented at least $50 \%$ of the total planktonic biomass and at least $70 \%$ of the carbon retained by M. edulis.

Similarly to these two species, we report for P. margaritifera that (i) natural variations in the composition and abundance of plankton lead to important feeding variations (ii) particles of size $>$ $2 \mu \mathrm{m}$ are the main source of carbon.

\section{Conclusion and perspectives}

The grazing experiments conducted in Ahe lagoon with the flow trough chamber method confirmed the in situ high clearance rates of $P$. margaritifera and highlighted the strong relationship between clearance rates and plankton size/biovolume. Our results also clearly demonstrated that, even if atoll lagoons of Tuamotu Archipelago are characterized by a low average biomass of plankton, the variations of this biomass and the variations in the structure of planktonic communities have a major influence on the feeding of pearl oysters. This will help on the long run to understand the inter-lagoon differences of pearl oysters' ecophysiology (growth, reproduction, see Fournier et al., This issue) and therefore the inter-lagoon differences in aquaculture an pearl farming potential. However, food sources of P. margaritifera are highly diversified (Loret et al., 2000a; Nasr, 1984) and it is obvious that several plankton taxa/types were not considered in the present study due to their low concentration such as diatoms, small metazooplankton, coccolithophorids.

Despite their average low abundance, transitory peaks of diatoms, bivalve larvae and other metazoan larvae concentration have been observed in atoll lagoons (Fournier et al., this issue; Pagano et al, this issue; Sournia and Ricard, 1976). These plankton fractions may therefore 
represent significant food sources for pearl oysters.

For these reasons, further studies on pearl oysters nutrition should focus on the measurement of clearance rates and carbon retention rates of small metazooplankton, coccolithophorids and diatoms.

\section{ACKNOWLEDGEMENT}

This study was supported by the European Development Fund, in collaboration with the Service de la Perliculture, the University of French Polynesia and the Institut Français de Recherche pour l'Exploitation de la Mer (Ifremer). We thank the Ifremer and Service de la Perliculture staff for their efficient help during field work; the Pa'umotu: R. and W. Richmond, T. Coulombe and M. Maifano, for their effective assistance on Ahe Atoll. We acknowledge the two anonymous reviewers and Serge Andréfouët for their comments.

\section{REFERENCES}

Andréfouët, S., Pagès, J., Tartinville, B., 2001. Water renewal time for classification of atoll lagoons in the Tuamotu Archipelago (French Polynesia). Coral Reefs 20, 399-408.

Bayne, B., 2004. Comparisons of measurements of clearance rates in bivalve molluscs. Marine Ecology Progress Series 276, 305-306.

Buestel, D., Pouvreau, S., 2000. Particulate matter in Takapoto lagoon waters : potential food for cultivated pearl oysters. Oceanologica Acta 23, 193-210.

Charpy, L., 1996. Phytoplankton biomass and production in two Tuamotu atoll lagoons ( French Polynesia ). Marine Ecology Progress Series 145, 133-142.

Charpy, L., Blanchot, J., 1998. Photosynthetic picoplankton in French Polynesian atoll lagoons:estimation of taxa contribution to biomass and production by flow cytometry. Marine Ecology Progress Series 162, 57-70.

Charpy, L., Charpy-Roubaud, C., 1990. Trophic structure and productivity of the lagoonal communities of Tikehau atoll (Tuamotu Archipelago, French Polynesia). Hydrobiologia 207, 43-52.

Charpy, L., Dufour, P., Garcia, N., 1997. Particulate organic matter in sixteen Tuamotu atoll lagoons (French Polynesia). Marine Ecology Progress Series 151, 55-65.

Charpy, L., Rodier, M., Fournier, J., Langlade, MJ., Gaertner-Mazouni, N., 2012. Physical and chemical control of the phytoplankton of Ahe lagoon, French Polynesia. Marine Pollution Bulletin, This issue.

Critchlow, D., Fligner, M., 1991. On distribution-free multiple comparisons in the one way analysis of variance. communication in statistics-Theory and methods 20, 127-139.

Delesalle, B., Sournia, A., 1992. Residence time of water and phytoplankton biomass in coral reef lagoons. Continental Shelf Research 12, 939-949.

Dumas, F., Le Gendre, R., Andréfouët, S., this issue. Tidal flushing and wind driven circulation of Ahe lagoon (Tuamotu Archipelago, French Polynesia) from in situ observations and numerical 
modelling. Marine Pollution Bulletin.

Dupuy, C., Vaquer, A., Lam-Höai, T., Rougier, C., Mazouni, N., Lautier, J., Collos, Y., Le Gall, S. Le., 2000. Feeding rate of the oyster Crassostrea gigas in a natural planktonic community of the Mediterranean Thau Lagoon. Marine Ecology Progress Series 205, 171-184.

Efron, B., Tibshirani, R., 1986. Bootstrap Methods for Standard Errors, Confidence Intervals, and Other Measures of Statistical Accuracy. Statistical Science 1, 54-77.

Ferrier-Pagès, C., Furla, P., 2001. Pico- and nanoplankton biomass and production in the two largest atoll lagoons of French Polynesia. Marine Ecology Progress Series 211, 63-76.

Filgueira, R., Labarta, U., Fernandez-Reiriz, M., 2006. Flow-through chamber method for clearance rate measurements in bivalves : design and validation of individual chambers and mesocosm. Limnology and Oceanography : Methods 284-292.

Fournier, J., Levesque, E., Pouvreau, S., Le Pennec, M., Le Moullac, G., 2012. Influence of plankton concentration on gametogenesis and spawning of the black lip pearl oyster $P$ margaritifera in ahe atoll lagoon (Tuamotu Archipelago, French Polynesia). Marine Pollution Bulletin, This issue.

González, J., Torréton, J., Dufour, P., Charpy, L., 1998. Temporal and spatial dynamics of the pelagic microbial food web in an atoll lagoon. Aquatic Microbial Ecology 16, 53-64.

Gundersen, K., Heldal, M., Norland, S., Purdie, D., Knap, A., 2002. Elemental C, N and P cell content of individual bacteria collected at the Bermuda Atlantic Time-series Study (BATS) site. Limnology and Oceanography 47, 1525-1530.

Hawkins, A., James, M., Hickman, R., Hatton, S., Weatherhead, M., 1999. Modelling of suspension-feeding and growth in the green-lipped mussel Perna canaliculus exposed to natural and experimental variations of seston availability in the Marlborough Sounds, New Zealand. Marine Ecology Progress Series 191, 217-232.

Hildreth, D., Crisp, D., 1976. A corrected formula for calculation of filtration rate of bivalve molluscs in an experimental flowing system. Journal of the marine biological association of U.K 111-120.

Jørgensen, C., 1996. Bivalve filter feeding revisited. Marine Ecology Progress Series 142, 287-302.

Kahl, A., 1931. Urtiere oder protozoa, in Dahl, F., Dahl, M., Bischoff, H. (eds.), Die Tierwelt Deutschlands und der angrenzenden Meeresteile. Gustav Fischer, Jena.

Lee, J., Hutner, S., Bovee, E. (Eds.), 1985. An illustrated Guide to the Protozoa.Allen Press, Lawrence, KS.

Loret, P., Le Gall, S., Dupuy, C., Blanchot, J., Pastoureaud, A., Delesalle, B., Caisey, X., Jonquières, G., 2000a. Heterotrophic protists as a trophic link between picocyanobacteria and the pearl oyster Pinctada margaritifera in the Takapoto lagoon (Tuamotu Archipelago, French Polynesia). Aquatic Microbial Ecology 22, 215-226.

Loret, P., Pastoureaud, A., Bacher, C., Delesalle, B., 2000b. Phytoplankton composition and selective feeding of the pearl oyster Pinctada margaritifera in the Takapoto lagoon (Tuamotu Archipelago, French Polynesia):in situ study using optical microscopy and HPLC pigment analysis. Marine Ecology Progress Series 199, 55-67.

Marie, D., Partensky, F., Jacquet, S., Vaulot, D., 1997. Enumeration and cell analysis of natural populations of marine picoplankton by flow cytometry using the nucleic acid stain SYBR Green I. Applied and Environmental Microbiology 63, 186-193.

Menden-Deuer, S., Lessard, E., 2000. Carbon to volume relationships for dinoflagellates, diatoms, 
and other protist plankton. Limnology and Oceanography 45, 569-579.

Nasr, D.H., 1984. Feeding and growth of the pearl oyster Pinctada margaritifera ( L .) in Dongonab Bay, Red Sea. Hydrobiologia 110, 241-245.

Nezan, E., 1996. Surveillance du Phytoplankton marin : manuel illustré adapté à la formation des analystes. (IFREMER, Eds.). Brest.

Niquil, N., Jackson, G., Legendre, L., Delesalle, B., 1998. Inverse model analysis of the planktonic food web of Takapoto Atoll (French Polynesia). Marine Ecology Progress Series 165, 17-29.

Pagano, M., Sagarra, P., Champalbert, G., Bouvy, M., Dupuy, C., Thomas, Y., Charpy, L., 2012. Metazooplankton communities in Ahe atoll lagoon (Tuamotu Archipelago, French Polynesia) : spatiotemporal variations and trophic relationships. Marine Pollution Bulletin, This issue.

Pascoe, P., Parry, H., Hawkins, A., 2009. Observations on the measurement and interpretation of clearance rate variations in suspension-feeding bivalve shellfish. Aquatic Biology 6, 181-190.

Paulmier, G., 1997. Tintinnides (Ciliophora, Oligotrichida, Tintinnina) de l'ata lntique boréal, de l'océan indien et de quelques mers adjacentes : Mediterranée, mer Caraïbe, mer Rouge. Inventaires et distribution. Observations basées sur les loricas. (IFREMER, Eds.). Brest.

Petersen, J., 2004. Methods for measurement of bivalve clearance rate-hope for common understanding. Marine Ecology Progress Series 276, 309-310.

Pouvreau, S., Bacher, C., Héral, M., 2000a. Ecophysiological model of growth and reproduction of the black pearl oyster, Pinctada margaritifera: potential applications for pearl farming in French Polynesia. Aquaculture 186, 117-144.

Pouvreau, S., Bodoy, A., Buestel, D., 2000b. In situ suspension feeding behaviour of the pearl oyster, Pinctada margaritifera: combined effects of body size and weather-related seston composition. Aquaculture 181, 91-113.

Pouvreau, S., Jonquières, G., Buestel, D., 1999. Filtration by the pearl oyster, Pinctada margaritifera, under conditions of low seston load and small particle size in a tropical lagoon habitat. Aquaculture 176, 295-314.

Ricard, M., 1987. Atlas du phytoplancton marin, vol. 2. (CNRS, Eds.). Paris.

Riisgård, H., 2001. On measurement of filtration rates in bivalves-the stony road to reliable data: review and interpretation. Marine Ecology Progress Series 211, 275-291.

Riisgård, H., 2004. Intercalibration of methods for measurement of bivalve filtration rates-a turning point. Marine Ecology Progress Series 276, 307-308.

Sakka, A., Legendre, L., Gosselin, M., Delesalle, B., 2000. Structure of the oligotrophic planktonic food web under low grazing of heterotrophic bacteria:Takapoto Atoll, French Polynesia. Marine Ecology Progress Series 197, 1-17.

Silverman, H., Lynn, J., Dietz, T., 1996. Particle Capture by the Gills of Dreissena polymorpha: Structure and Function of Latero-frontal Cirri. Biological Bulletin 191, 42-54.

Sournia, A., 1986. Atlas du phytoplancton marin, vol. 1. (CNRS, Eds.). Paris.

Sournia, A., Ricard, M., 1976. Données sur l'h ydrologie et la producativité d'un atoll fermé (Takapoto, Iles Tuamotu). Vie Milieu 26, 243-279.

Spurrier, J., 2006. Additional Tables for Steel-Dwass-Critchlow-Fligner Distribution-Free Multiple Comparisons of Three Treatments. Communications in Statistics - Simulation and Computation 35, 441-446.

Thomas, Y., Garen, P., Bennett, A., Le Pennec, M., Clavier, J., 2012. Multiscale distribution and dynamics of bivalve larvae in a deep atoll lagoon (Ahe, French Polynesia). Marine Pollution 
Thomas, Y., Garen, P., Courties, C., Charpy, L., 2010. Spatial and temporal variability of the picoand nanophytoplankton and bacterioplankton in a deep Polynesian atoll lagoon. Aquatic microbial ecology 59, 89-101.

Torréton, J., Pagès, J., Talbot, V., 2002. Relationships between bacterioplankton and phytoplankton biomass, production and turnover rate in Tuamotu atoll lagoons. Aquatic Microbial Ecology 28, 267-277.

Trottet, A., Roy, S., Tamigneaux, E., Lovejoy, C., Tremblay, R., 2008. Impact of suspended mussels (Mytilus edulis L.) on plankton communities in a Magdalen Islands lagoon (Québec, Canada): A mesocosm approach. Journal of Experimental Marine Biology and Ecology 365, 103-115.

Troussellier, M., Courties, C., Zettelmaier, S., 1995. Flow cytometric analysis of coastal lagoon bacterioplankton and picophytoplankton : fixation and storage effects. Aquatic Microbial Ecology 40, 113-119.

Verity, P., Robertson, C., Tronzo, C., Andrews, M., Nelson, J., Sieracki, M., 1992. Relationship between cell volume and the carbon and nitrogen content of marine photosynthetic nanoplankton. Limnology and Oceanography 37, 1434-1446.

Welschmeyer, N., 1994. Fluorometric analysis of chlorophyll a in the presence of chlorophyll $\mathrm{b}$ and pheopigments. Limnology and Oceanography 39, 1985-1992.

Wright, R., Coffin, R., Ersing, C., Pearson, D., 1982. Field and laboratory measurements of bivalve filtration of natural marine bacterioplankton. Limnology and oceanography 27, 91-98.

Yukihira, H., Klumpp, D., Lucas, J., 1998a. Comparative effects of microalgal species and food concentration on suspension feeding and energy budgets of the pearl oysters Pinctada margaritifera and P. maxima (Bivalvia:Pteriidae). Marine Ecology Progress Series 171, 71-84.

Yukihira, H., Klumpp, D., Lucas, J., 1998b. Effects of body size on suspension feeding and energy budgets of the pearl oysters Pinctada margaritifera and P. maxima. Marine Ecology Progress Series 170, 119-130. 
Table 1 : Mean height \pm standard deviation (in $\mathrm{mm}$ ) and number of oysters (between parentheses) used during our experiments. Sampling strategy $(n)$ for the measurement of clearance rates of pearl oysters (Pico. = picoplankton, Nano. $=$ nanoflagellates, Dino. $=$ dinoflagellates, Cili. $=$ Ciliates, Chl. $a<2 \mu \mathrm{m}$ and Chl. $a>2 \mu \mathrm{m}=$ phytoplankton $<2 \mu \mathrm{m}$ and $>2 \mu \mathrm{m})$

Survey Oysters Height Chl. $a(n)$ Pico. (n) Nano. (n) Dino. $(n)$ Cili. $(n)$

\begin{tabular}{lcccccc}
\hline May 2008 & $42 \pm 1(4)$ & 8 & & & \\
& $113 \pm 4(2)$ & 9 & - & - & - \\
October 2008 & $28 \pm 2(4)$ & 30 & 22 & 15 & 10 & 10 \\
May 2009 & $75 \pm 6(6)$ & 50 & - & - & - & - \\
\hline
\end{tabular}

Table 2 : Mean $\pm 95 \%$ confidence interval of wind velocity $\left(\mathrm{m} \mathrm{s}^{-1}\right)$, water temperature $\left({ }^{\circ} \mathrm{C}\right)$ and salinity (PSU) measured in May 2008, October 2008 and April/May 2009.

\begin{tabular}{llll} 
Survey & Wind Velocity & Water Temp. & Salinity \\
\hline May 2008 & $2.83 \pm 0.86$ & $28.22 \pm 0.03$ & $36.87 \pm 0.09$ \\
October 2008 & $8.63 \pm 0.41$ & $26.82 \pm 0.01$ & $36.16 \pm 0.3$ \\
May 2009 & $2.65 \pm 0.62$ & $29.10 \pm 0.05$ & $36.23 \pm 0.01$ \\
\hline
\end{tabular}

Table 3 : Abundance (in Cell $1^{-1}$ or in $\mu \mathrm{gChl} a \mathrm{l}^{-1}$ ), Carbon biomass (CB in $\mu \mathrm{gC} \mathrm{l}^{-1}$ and $\mathrm{B}$ in \%), Clearance Rates of pearl oysters ( in $1 \mathrm{~h}^{-1} \mathrm{~g}^{-1}$ ) and carbon retention rates (Carbon Retained in $\mu \mathrm{gC} \mathrm{h}^{-1} \mathrm{~g}^{-1}$ and Carb. in \%) measured in May 2008 , October 2008 and April/May 2009 at our study site (Pico. = picoplankton, Nano. = nanoflagellates, Dino. = dinoflagellates, Cili. $=$ Ciliates, Chl. $a<2 \mu \mathrm{m}$ and Chl. $a>2 \mu \mathrm{m}=$ phytoplankton $<2 \mu \mathrm{m}$ and $>2 \mu \mathrm{m})$.

\begin{tabular}{|c|c|c|c|c|c|c|c|c|c|}
\hline Survey & Plankton Type & Abundance & $\mathrm{CB}$ & B $(\%)$ & & Clearance Rates & $\begin{array}{c}\text { Carbon } \\
\text { Retained }\end{array}$ & $\begin{array}{c}\text { Carb } \\
(\%)\end{array}$ & \\
\hline \multirow[t]{2}{*}{ May 2008} & Chl $a>2 \mu \mathrm{m}$ & $0.10 \pm 0.03$ & 5 & 13 & & $14.4 \pm 6.0$ & 72 & 32 & \\
\hline & Chl $a<2 \mu \mathrm{m}$ & $0.41 \pm 0.08$ & 34 & 87 & & $4.5 \pm 6.2$ & 152 & 68 & \\
\hline \multirow[t]{6}{*}{ October 2008} & Chl $a>2 \mu \mathrm{m}$ & $0.34 \pm 0.32$ & 17 & 40 & & $13.7 \pm 7.8$ & 233 & 72 & \\
\hline & Chl $a<2 \mu \mathrm{m}$ & $0.30 \pm 0.06$ & 25 & 60 & & $3.7 \pm 2.5$ & 92 & 28 & \\
\hline & Pico. & $2.64 \pm 0.71 \times 10^{8}$ & 28 & 10 & \multirow{4}{*}{ இ̊ } & $0.5 \pm 5.4$ & 15 & 0 & \\
\hline & Nano. & $5.25 \pm 0.80 \times 10^{7}$ & 247 & 85 & & $11.8 \pm 6.6$ & 2918 & 93 & 2 \\
\hline & Dino. & $5.09 \pm 4.32 \times 10^{4}$ & 11 & 4 & & $15.9 \pm 4.1$ & 179 & 6 & $\underline{\underline{E}}$ \\
\hline & Cili. & $740 \pm 354$ & 2 & 1 & & $18.7 \pm 10.0$ & 29 & 1 & \\
\hline \multirow[t]{2}{*}{ May 2009} & Chl $a>2 \mu \mathrm{m}$ & $0.14 \pm 0.06$ & 7 & 30 & & $14.6 \pm 5.0$ & 102 & 53 & \\
\hline & Chl $a<2 \mu \mathrm{m}$ & $0.20 \pm 0.06$ & 16 & 70 & & $5.6 \pm 2.5$ & 92 & 47 & \\
\hline
\end{tabular}

Table 4 : Analysis of variance table for statistical comparisons of concentration Chl. $a$ and standardized clearance rates of pearl oysters within size class of Chl. $a(>2 \mu \mathrm{m}$ and $<2 \mu \mathrm{m})$ and between survey.

\begin{tabular}{lllll} 
Analysis & Source & $d f$ & $F$ & $p$ \\
\hline Chl. $a$ concentration among survey and size & Size class & 1 & 25.3 & 0.000 \\
class of Chl $a$ & Survey & 2 & 17.9 & 0.000 \\
& Interaction & 2 & 21.0 & 0.000
\end{tabular}


Table 5 : Average biovolumes (BV in $\mu \mathrm{m}^{3}$ ) and carbon content (C.C. in $\mu \mathrm{gC} \mathrm{Cell}{ }^{-1}$ or in $\mu \mathrm{gC} \mu \mathrm{gChl} a^{-1}$ ) computed from our data and from litterature data (Pico. $=$ picoplankton, Nano. $=$ nanoflagellates, Dino. $=$ dinoflagellates, Cili. $=$ Ciliates, Chl. $a<2 \mu \mathrm{m}$ and Chl. $a>2 \mu \mathrm{m}=$ phytoplankton $<2 \mu \mathrm{m}$ and $>2 \mu \mathrm{m}$ ).

\begin{tabular}{lll} 
Plankton type & B.V. & C.C. \\
\hline Pico. & 0.25 & $1.1 \times 10^{-7}$ \\
Nano. & 509 & $4.7 \times 10^{-6}$ \\
Dino. & 1606 & $2.2 \times 10^{-4}$ \\
Cili. & 18091 & $2.1 \times 10^{-3}$ \\
Chl. $a>2 \mu \mathrm{m}$ & - & 50 \\
Chl. $a<2 \mu \mathrm{m}$ & - & 82 \\
\hline
\end{tabular}

Table 6 : Relationship between clearance rates of pearl oyster $\left(\mathrm{CR}_{\mathrm{Chl} a<2 \mu \mathrm{m}}\right.$ and $\left.\mathrm{CR}_{\mathrm{Chl} a>2 \mu \mathrm{m}}\right)$, concentration of phytoplankton $<2 \mu \mathrm{m}(\mathrm{Chl} a<2 \mu \mathrm{m})$, of phytoplankton $>2 \mu \mathrm{m}(\mathrm{Chl} a>2 \mu \mathrm{m})$, and flow rates in the grazing chambers. Pearson's product moment correlation $(r)$ and p-values $(p)$ are indicated for each analysis.

\begin{tabular}{lll} 
& $\mathrm{CR}_{\mathrm{Chl} a<2 \mu \mathrm{m}}$ & $\begin{array}{l}\mathrm{CR} \\
\text { Chl } a>\end{array}$ \\
\hline \multirow{2}{*}{ Chl $a>2 \mu \mathrm{m}$} & $r=-0.08$ & $r=0.09$ \\
& $p=0.434$ & $p=0.348$ \\
Chl $a<2 \mu \mathrm{m}$ & $r=0.01$ & $r=-0.04$ \\
& $p=0.970$ & $p=0.717$ \\
Flow rates & $r=0.20$ & $r=0.08$ \\
& $p=0.050$ & $p=0.415$
\end{tabular}

Table 7 : Range of plankton concentration (in $\mu \mathrm{gChl} a \mathrm{l}^{-1}$ or in Cell $1^{-1}$ ) measured during our experiments (This study), at other sites/periods in Ahe atoll lagoon (Ahe) and in other French Polynesian atoll lagoons (Other atolls).

\begin{tabular}{llll} 
& This study & Ahe & Other atolls \\
\hline Chlorophyll $a$ & $0.25-1.76$ & $0.08-0.85^{\mathrm{a}}$ & $0.02-1.24^{\mathrm{e}}$ \\
Picoplankton. $\left(\mathrm{x} 10^{8}\right)$ & $1.9-3.1$ & $1.0-5.1^{\mathrm{b}}$ & $2.2-23.2^{\mathrm{e}}$ \\
$\quad$ Bacteria. $\left(\mathrm{x} 10^{8}\right)$ & $0.6-1.9$ & $2.6-7.8^{\mathrm{b}}$ & $2.2-20.7^{\mathrm{e}}$ \\
$\quad$ Synecocochus. $\left(\mathrm{x} 10^{8}\right)$ & $0.6-1.4$ & $0.8-1.2^{\mathrm{b}}$ & $<0.1-2.8^{\mathrm{e}}$ \\
$\quad$ Prochlorococcus. $\left(\mathrm{x} 10^{8}\right)$ & $0.1-0.8$ & $0.6-1.4^{\mathrm{b}}$ & $<0.1-1.7^{\mathrm{e}}$ \\
$\quad$ Picoeukaryotes. $\left(\mathrm{x} 10^{6}\right)$ & $1.4-5.3$ & $2.8-4.6^{\mathrm{b}}$ & $<0.1-4.9^{\mathrm{e}}$ \\
Nanoflagellates. $\left(\mathrm{x} 10^{6}\right)$ & $37.0-67.0$ & $5.5-8.5^{\mathrm{c}}$ & $0.7-2.0^{\mathrm{f}}$ \\
Dinoflagellates. $\left(\mathrm{x} 10^{5}\right)$ & $0.09-1.2$ & $<0.01-0.03^{\mathrm{d}}$ & $<0.01-1.90^{\mathrm{g}}$ \\
Ciliates. $\left(\mathrm{x} 10^{3}\right)$ & $0.3-1.1$ & $<0.01-0.9^{\mathrm{d}}$ & $<0.01-4.0^{\mathrm{g}}$
\end{tabular}

(a) Thomas et al. (2010), Fournier et al. (this issue), Charpy et al. (this issue); ${ }^{\left({ }^{b}\right)}$ Thomas et al. (2010); (c) Dupuy, (Pers. Com.); ${ }^{(\mathrm{d})}$ Fournier et al. (this issue); ${ }^{\mathrm{e})}$ Charpy \& Blanchot (1998), Torreton et al. (2002); ${ }^{(\mathrm{f})}$ González et al. (1998); ${ }^{\mathrm{g})}$ González et al. (1998), Loret et al. (2000a). 
Table 8 : Average abundance (in Cell $\mathrm{l}^{-1}$ or in $\mu \mathrm{gChl} a \mathrm{l}^{-1}$ ), Carbon biomass (CB in $\mu \mathrm{gC} 1^{-1}$ and $\mathrm{B}$ in \%), and carbon retention rates of pearl oysters (Carbon Retained in $\mu \mathrm{gC} \mathrm{h}^{-1} \mathrm{~g}^{-1}$ and Carb. in \%) in Ahe lagoon. (Pico. = picoplankton, Nano. $=$ nanoflagellates, Dino. $=$ dinoflagellates, Cili. $=$ Ciliates, Chl. $a<2 \mu \mathrm{m}$ and Chl. $a>2 \mu \mathrm{m}=$ phytoplankton $<$ $2 \mu \mathrm{m}$ and $>2 \mu \mathrm{m})$.

\begin{tabular}{|c|c|c|c|c|c|c|c|}
\hline Plankton Type & Abundance & CB & B $(\%)$ & & $\begin{array}{l}\text { Carbon } \\
\text { Retained }\end{array}$ & Carb (\%) & \\
\hline Chl $a>2 \mu \mathrm{m}$ & $0.14^{\text {(a) }}$ & 7 & 27 & & 102 & 49 & \\
\hline Chl $a<2 \mu \mathrm{m}$ & $0.23^{(a)}$ & 19 & 73 & & 105 & 51 & \\
\hline Pico. & $6.5 \times 10^{8(b)}$ & 71 & 69 & \multirow{4}{*}{ ஓ̊ } & 38 & 8 & \multirow{4}{*}{ 号 } \\
\hline Nano. & $5.3 \times 10^{6(\mathrm{c})}$ & 25 & 24 & & 293 & 64 & \\
\hline Dino. & $2.0 \times 10^{4(a)}$ & 4 & 4 & & 70 & 15 & \\
\hline Cil. & $1.4 \times 10^{4(a)}$ & 3 & 3 & & 55 & 12 & \\
\hline
\end{tabular}

(a) Fournier et al. (this issue); ${ }^{\text {(b) }}$ Thomas et al. (2010); ${ }^{\text {(c) }}$ Dupuy C., (Unp. data.) 
Figure 1 : Location of Ahe atoll. Location of the sites where filtration experiments were carried out (site F) and where we measured water temperature and salinity (site T) in Ahe lagoon (map by courtesy of Yoann Thomas).

Figure 2 : Flow through grazing chambers were divided into 3 compartments : inflow compartment, grazing compartment and outflow compartment.

Figure 3 : Abundance of plankton (graphs a, c and e) and clearance of pearl oysters (graphs b, $d$ and f) measured in May 2008, October 2008 and April/May 2009 in Ahe lagoon. (Pico. = picoplankton, Nano. = nanoflagellates, Dino. $=$ dinoflagellates, Cili. $=$ Ciliates, Chl. $a<2 \mu \mathrm{m}$ and Chl. $a>2 \mu \mathrm{m}=$ phytoplankton $<2 \mu \mathrm{m}$ and $>2 \mu \mathrm{m})$.

Figure 4 : Allometric relationship between clearance rates (CRi in $1 \mathrm{~h}^{-1}$ ) and freeze dried flesh weight (DW in $\mathrm{g}$ ) of pearl oysters. Each point represents the mean individual clearance rates of pearl-oysters $(\mathrm{Chl} a>2 \mu \mathrm{m})$ with bars corresponding to standard deviation. The curve corresponds to the equation $\mathrm{CRi}=13.3 \times \mathrm{DW}^{0.62}$.

Figure 5 : Relationship between standardized clearance rates of pearl oysters (CR in $1 \mathrm{~h}^{-1} \mathrm{~g}^{-1}$ ) and plankton biovolume (in $\mu \mathrm{m}^{3}$ ). Each point represents the mean CR of pearl-oysters measured in October 2008 in Ahe lagoon. (picolankton = full circle, nanoplankton $=$ empty triangle, dinoflagellates $=$ empty square and ciliates $=$ empty circle). Bars represent standard deviation. Curve represents the equation $\mathrm{CR}=0.42 \ln (\mathrm{BV})+0.35$. 
Figure 1
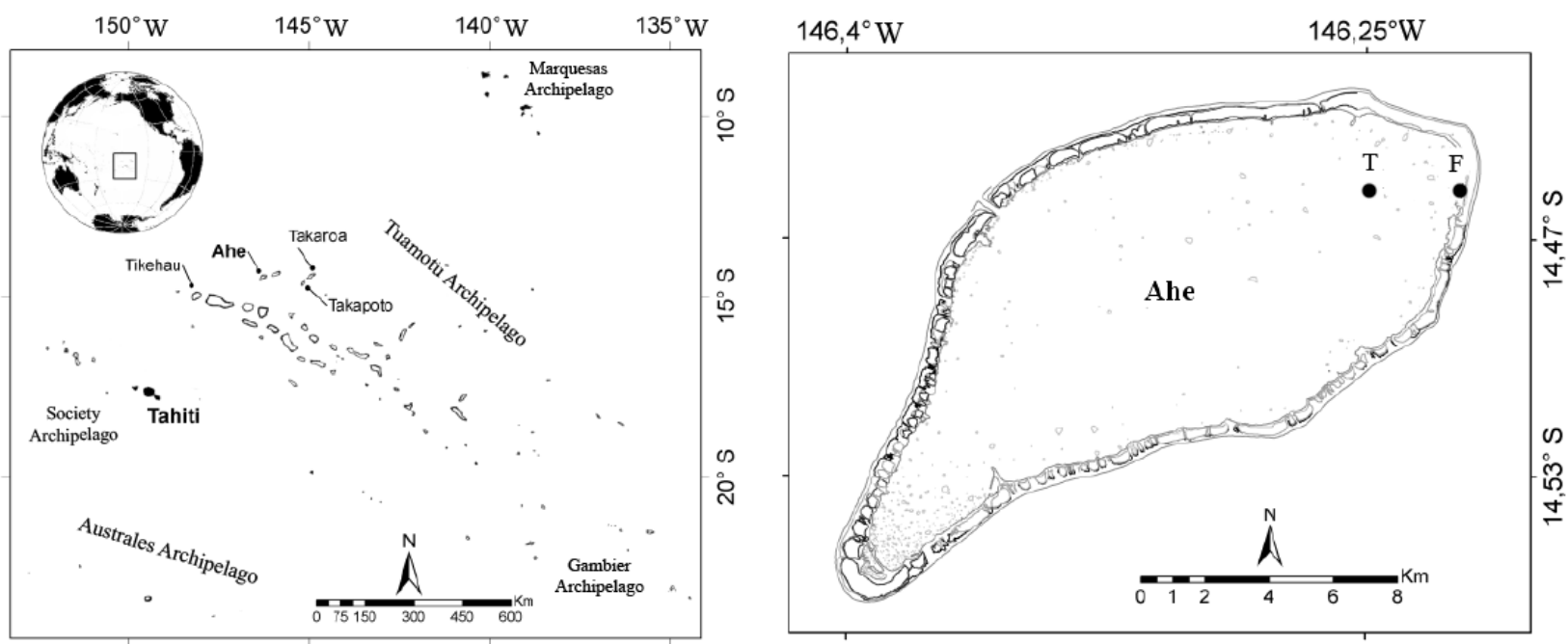
Figure 2

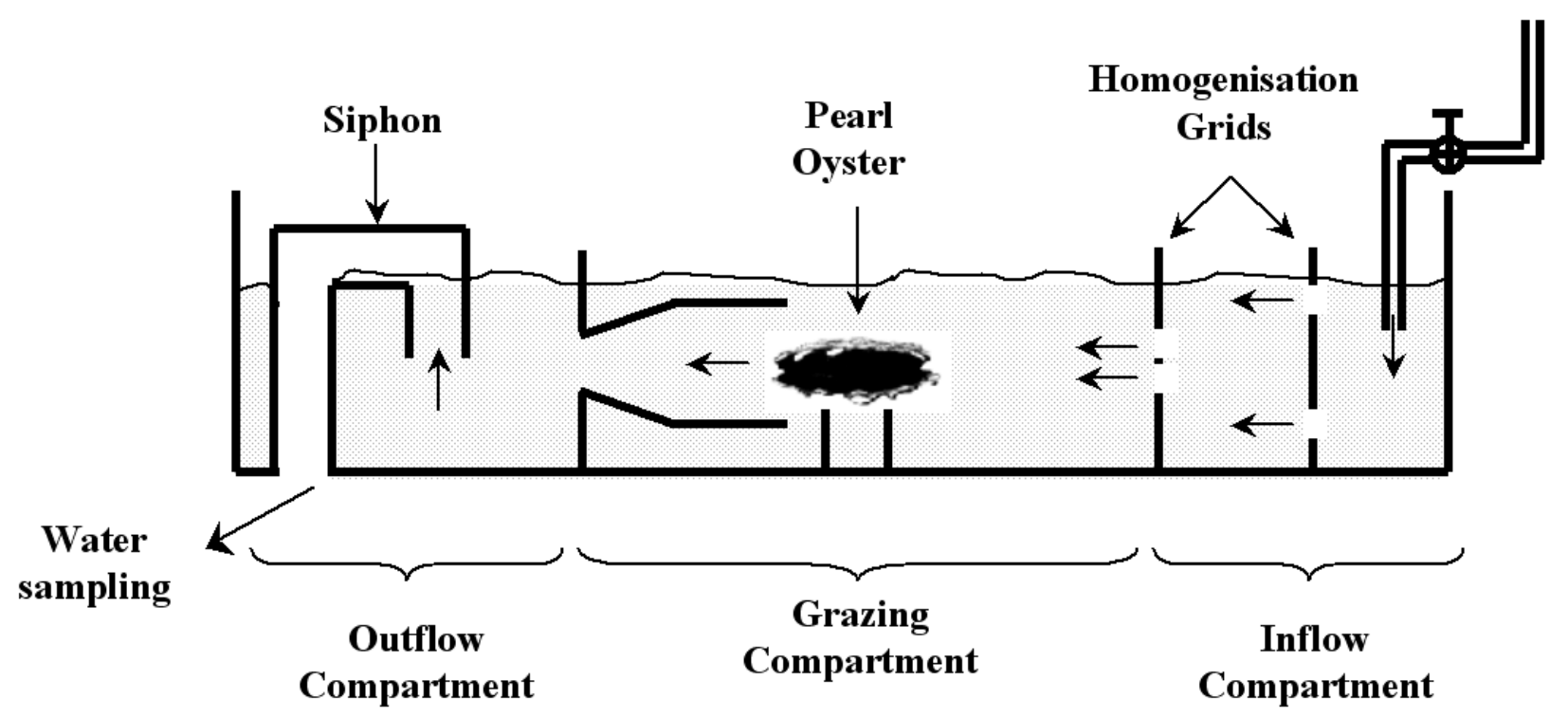



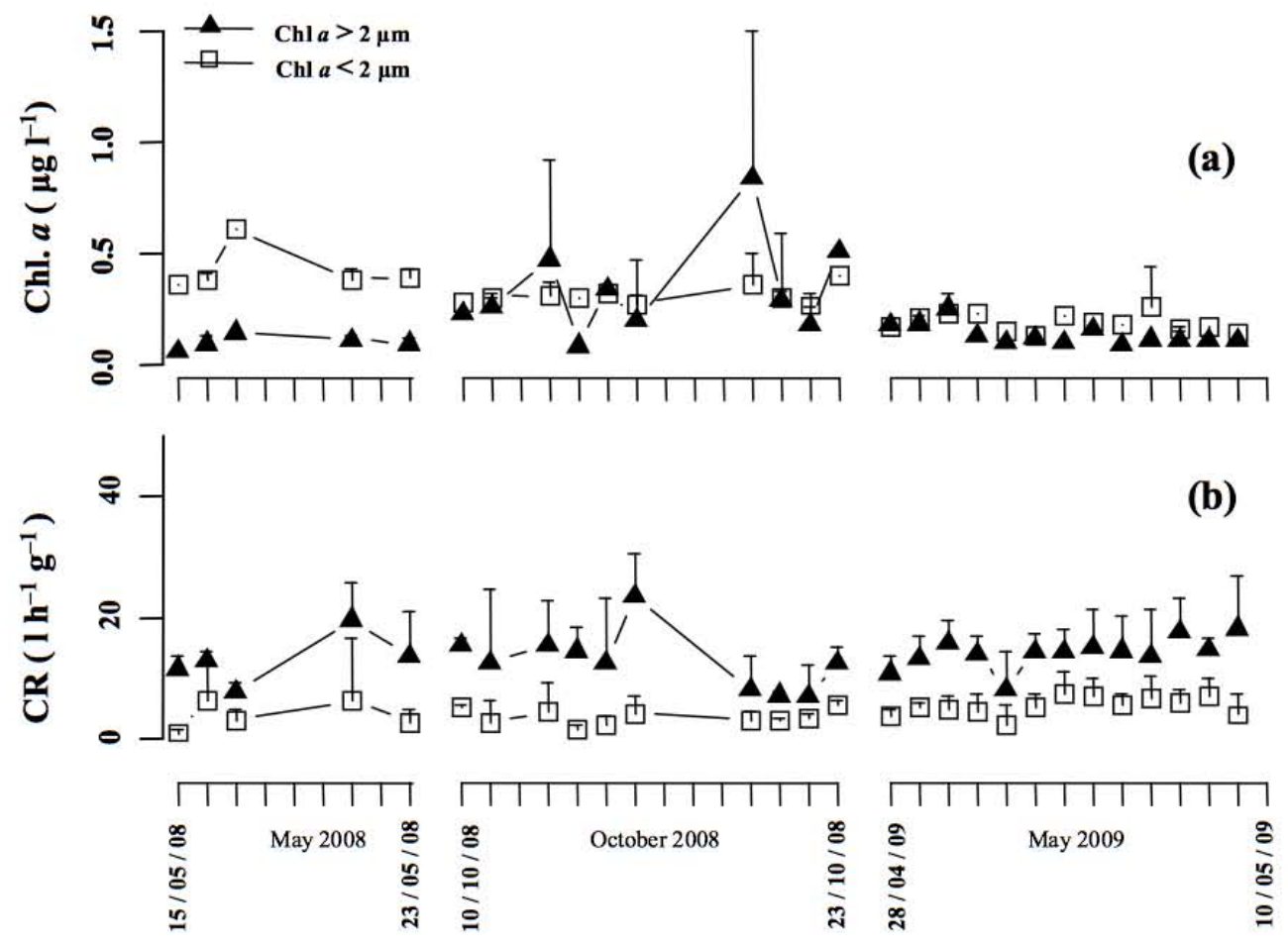

Days

(c)
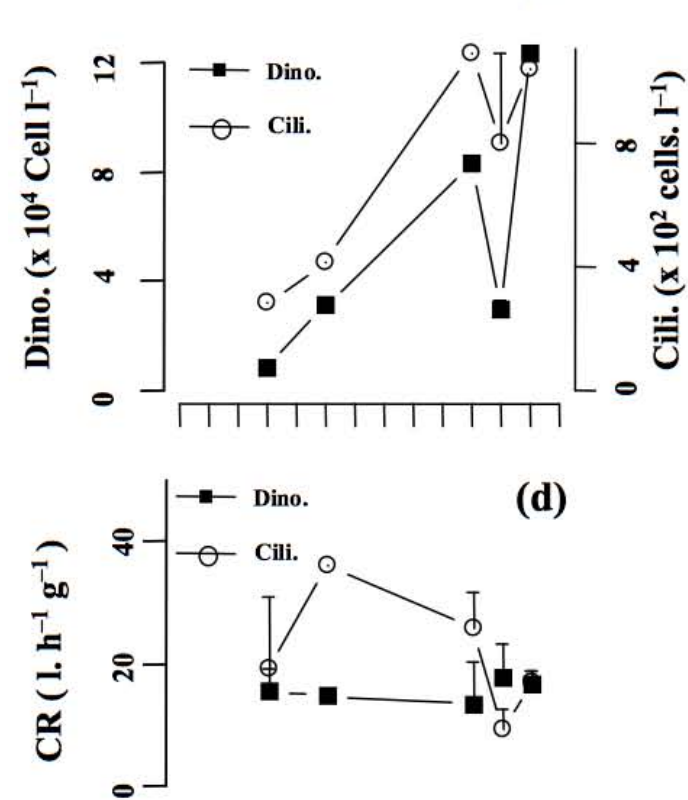

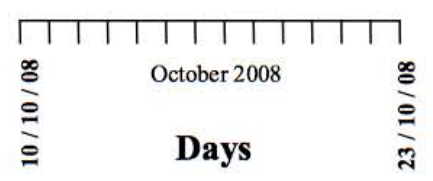

(d) (e)

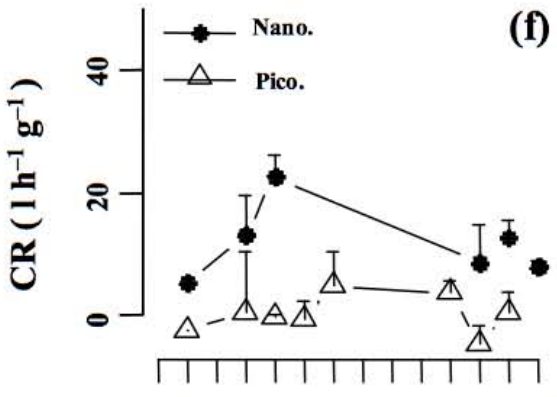

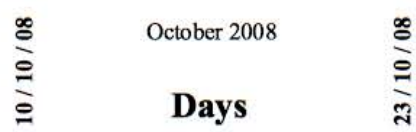




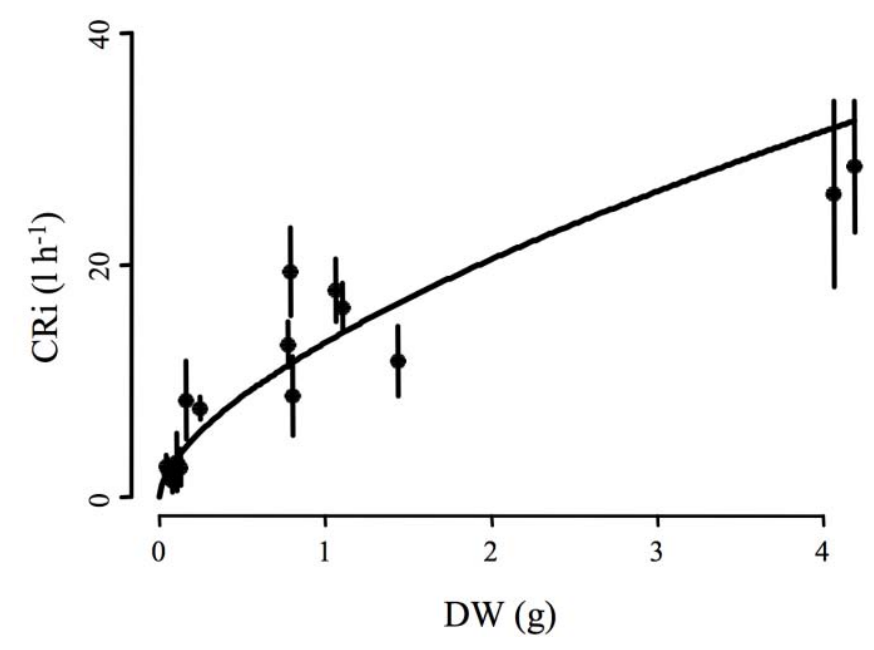

Figure 4 


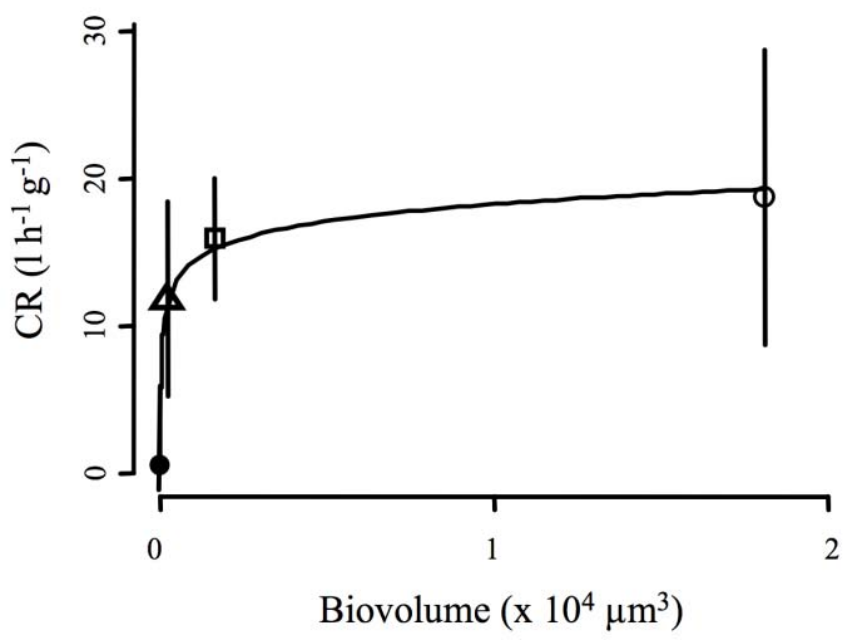

